\title{
Introduction to a special issue of Magnetic Resonance in honour of Robert Kaptein at the occasion of his 80th birthday
}

\author{
Rolf Boelens $^{1}$, Konstantin Ivanov ${ }^{2,3, \boldsymbol{t}}$, and Jörg Matysik ${ }^{4}$ \\ ${ }^{1}$ Bijvoet Centre for Biomolecular Research, Utrecht University, 3584 CH Utrecht, the Netherlands \\ ${ }^{2}$ International Tomography Center, Siberian Branch of the Russian Academy of Sciences, \\ Novosibirsk 630090, Russia \\ ${ }^{3}$ Department of Natural Sciences, Novosibirsk State University, Novosibirsk 630090, Russia \\ ${ }^{4}$ Institut für Analytische Chemie, Universität Leipzig, Linnéstraße 3, 04189 Leipzig, Germany \\ $\boldsymbol{t}_{\text {deceased, } 5 \text { March } 2021}$
}

Correspondence: Rolf Boelens (r.boelens@uu.nl) and Jörg Matysik (joerg.matysik@uni-leipzig.de)

Received: 20 May 2021 - Published: 17 June 2021

\begin{abstract}
This publication, in honour of Robert Kaptein's 80th birthday, contains contributions from colleagues, many of whom have worked with him, and others who admire his work and have been stimulated by his research. The contributions show current research in biomolecular NMR, spin hyperpolarisation and spin chemistry, including CIDNP (chemically induced dynamic nuclear polarisation), topics to which he has contributed enormously. His proposal of the radical pair mechanism was the birth of the field of spin chemistry, and the laser CIDNP NMR experiment on a protein was a major breakthrough in hyperpolarisation research. He set milestones for biomolecular NMR by developing computational methods for protein structure determination, including restrained molecular dynamics and 3D NMR methodology. With a lac repressor headpiece, he determined one of the first protein structures determined by NMR. His studies of the lac repressor provided the first examples of detailed studies of protein nucleic acid complexes by NMR. This deepened our understanding of protein DNA recognition and led to a molecular model for protein sliding along the DNA. Furthermore, he played a leading role in establishing the cluster of NMR large-scale facilities in Europe. This editorial gives an introduction to the publication and is followed by a biography describing his contributions to magnetic resonance.
\end{abstract}

\section{Introduction}

The special issue is dedicated to the 80th birthday, on 5 April 2021, of our esteemed colleague, Robert Kaptein, famous for his contributions to spin hyperpolarisation, spin chemistry and biomolecular NMR. In his doctoral research, Kaptein, when trying to explain the perplexing CIDNP (chemically induced dynamic nuclear polarisation) effect, proposed the radical pair mechanism and formulated the famous Kaptein rules, which describe the sign of the CIDNP signals. This development formed the basis for CIDNP as an efficient hyperpolarisation method, providing unique information about elusive short-lived radicals and radical pairs and leading to significant insight in the mechanisms of radical reactions. These results have become one of the cornerstones of an entire new field of science called spin chemistry. Later, Kaptein developed laser photo CIDNP as a selective and sensitive surface probe for studies of proteins and protein interactions in a solution. His interest in spin hyperpolarisation has not been limited to CIDNP; recently, he has also made valuable contributions in understanding the spin dynamics underlying parahydrogen-induced polarisation (PHIP) and signal amplification by reversible exchange (SABRE)-derived polarisation.

Robert Kaptein has also made prominent contributions to the computational and experimental methodology of biomolecular NMR and to the structure and dynamics of 


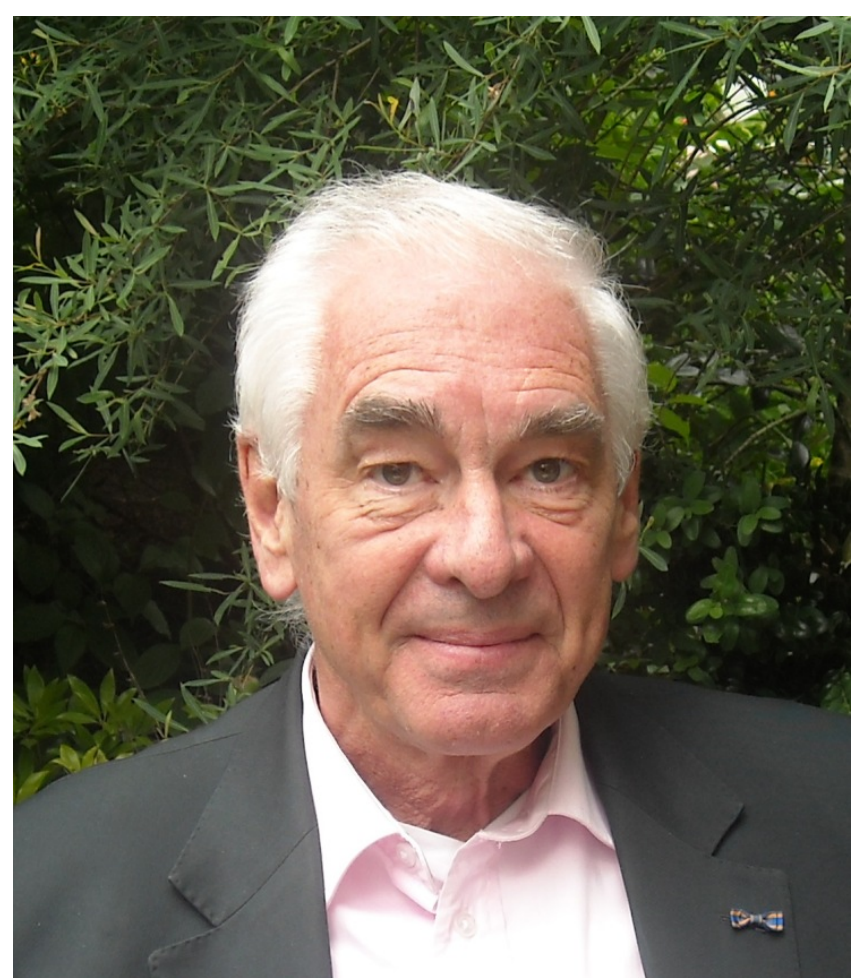

Figure 1. Robert Kaptein today.

gene regulatory proteins and protein DNA complexes. His laboratory developed, among others, non-selective homonuclear 3D NMR, restrained molecular dynamics and methods for relaxation matrix calculations and protein structure validation. The structure of the lac headpiece in 1985 was one of the first protein structures solved by NMR. This was followed by studies on the structure and dynamics of other gene regulatory proteins and protein DNA complexes, such as the glucocorticoid receptor, the Arc repressor and the POU domain of the transcription factor Oct-1. Central to his research has been the studies on the DNA complexes of the lac repressor that not only deepened our understanding of protein DNA recognition but also gave us a molecular model for protein sliding along the DNA. These studies have been of primary importance in establishing NMR as key method for studies on the structure and dynamics of proteins and protein complexes and an important stimulus in developing high-field NMR instrumentation and establishing national and international research infrastructures.

This special issue contains contributions from colleagues, many of whom have worked with Robert Kaptein over the years. The contributions show current research in biomolecular NMR, spin hyperpolarisation and spin chemistry, including CIDNP, all topics to which he has contributed enormously. This special issue nicely illustrates that these topics are still the focus of intense research now. We start with a biography in which we review the contributions of Robert Kaptein to magnetic resonance.

\section{Biography of Robert Kaptein}

This biography focusses on the scientific contributions to spin hyperpolarisation, spin chemistry and biomolecular NMR by Robert Kaptein in the magnetic resonance community. To write this biography, we made use of several historical overviews (Drenth, 2001; de Galan, 2004; Drenth and Verhoeven, 2004; van der Waals and Hilbers, 2004; Kaptein, 2007).

Kaptein studied chemistry at the University of Leiden and started his doctoral research in 1965 in Leiden with Luitzen J. Oosterhoff. The initial plan was to study stable free radicals with NMR. However, in 1967, Bargon and Fischer in Germany and Ward and Lawler in the USA discovered the phenomenon that, in organic chemical radical reactions, intense NMR emission and absorption signals can occur due to the resulting products (Bargon et al., 1967; Ward and Lawler, 1967). A good theoretical interpretation of this socalled CIDNP (chemically induced dynamic nuclear polarisation) effect had not been achieved yet. Kaptein became very interested and gave his thesis research a new direction, with full support by Oosterhoff. At that time, the effect was thought to be related to a dynamic nuclear polarisation (DNP) or Overhauser effect involving free radicals, but this interpretation was not satisfactory. Robert Kaptein - and independently also Gerhard Closs (Closs and Closs, 1969) was the first to realise that CIDNP formation occurs upon the recombination of radical pairs and provided a clear explanation of the CIDNP effect in three seminal papers (Kaptein and Oosterhoff, 1969a, b; Kaptein, 1972b). The theoretical analysis and results were part of his doctoral thesis in 1971 in Leiden (Kaptein, 1971b). The effects of the CIDNP net and multiplet emissions and absorptions in radical pair reactions could be fully explained by the described radical pair theory. Moreover, the full theory could also be summarised by the appealing so-called Kaptein's rules (Kaptein, 1971a). Using these practical equations, important conclusions could be drawn on the mechanism of radical reactions. His doctoral thesis is a mature and self-contained work that still can be used to learn about radical pair mechanisms and CIDNP. This work was followed by a series of articles with applications to different radical reactions (Kaptein et al., 1971a, b; Kaptein, 1972a, b; Kaptein and den Hollander, 1972; Kaptein et al., 1972, 1973, 1974, 1975; van Leeuwen et al., 1975; den Hollander and Kaptein, 1976).

After his doctorate, driven by the intention to learn about Fourier transform (FT) NMR (a new, fascinating subject in those days), Kaptein went to Varian in Palo Alto, California, for 1 year and worked with Ray Freeman as a postdoc. His work then was dealing with the first ${ }^{13} \mathrm{C}$ CIDNP detection by FT NMR and developing methods for quantitative ${ }^{13} \mathrm{C}$ NMR spectroscopy (Freeman et al., 1972). After returning to the Netherlands in 1972, Kaptein joined the KSLA (Royal Shell Laboratory Amsterdam), keeping ties to his colleagues 
in Leiden. Subsequently, he went back to an academic position.

In 1975, Robert Kaptein became the scientific supervisor of the Netherlands National NMR facility at the University of Groningen with one of the first $360 \mathrm{MHz}$ NMR instruments. He continued his research in the field of CIDNP, which resulted in developing the time-resolved CIDNP method which can be used for a detailed characterisation of the fast reactions of radicals and radical pairs (Hore et al., 1981; Hore and Kaptein, 1982; Hore et al., 1982). Kaptein also developed the photo CIDNP method in which laser-excited flavine dyes form a radical pair with residues at the surface of biomacromolecules (Kaptein et al., 1978). This leads to intense CIDNP effects of the aromatic NMR signals of tyrosine, tryptophan and histidine at the surface of the proteins when accessible for the dye. However, when these surface residues are involved in other interactions due to ligand binding or oligomerisation, the CIDNP signal enhancements are lost. This method enabled detailed functional NMR studies of proteins in a solution and initiated collaborations between Kaptein, in Groningen, with many biochemical groups in the Netherlands and abroad, as summarised in Kaptein (1982). A large number of studies of proteins and biomolecular complexes, using photo CIDNP, followed that allowed them to probe the role of the aromatic residues in these systems. These studies include the complex of the gene-5 protein with DNA with Cees Hilbers (Garssen et al., 1978); phospholipase A2 with Arend-Jan Slotboom, Gerard de Haas and Maarten Egmond (Jansen et al., 1978, 1979; Egmond et al., 1983); ribonuclease with Jaap Beintema (Lenstra et al., 1979); glyceraldehyde-3-phosphate dehydrogenase with Ruud Scheek and Jan Verhoeven (Scheek et al., 1979); colipase with Patrick Cozzone (Canioni et al., 1980); dihydrofolate reductase with Jim Feeney, Gordon Roberts and Angela Gronenborn (Feeney et al., 1980); streptomyces subtilisin inhibitor with Kazuyuki Akasaka (Akasaka et al., 1981); $\alpha$-lactalbumin with Larry Berliner (Berliner and Kaptein, 1981); flavodoxin with Franz Müller (Moonen et al., 1982); $\beta$-endorphin and oligophenols with Lucia Zetta (Zetta et al., 1982, 1988); the interaction of lac repressor with DNA with Heinz Rüterjans (Buck et al., 1983); $\gamma$-crystallin with Tom Schleich (Garner et al., 1984); lysozyme with Christina Redfield and Chris Dobson (Redfield et al., 1985); epidermal growth factor and plasminogen kringle domains with Antonio de Marco, Kevin Mayo and Miguel Llinas (de Marco et al., 1986a, b); sea anemone peptides with Ray Norton (Norton et al., 1986); and carbohydrate binding proteins with Hans-Christian Siebert, Hans Gabius and Hans Vliegenthart (Siebert et al., 1995, 1997). But, not only with proteins, the photo CIDNP effect could also be used to probe the accessibility of the aromatic bases in nucleotides and DNA (Kaptein et al., 1979), research that was more recently followed up by Alexandra Yurkovskaya (Morozova et al., 2007, 2008) and in a collaboration with Robert Kaptein (Morozova et al., 2012, 2013). Of course, as with any good rule, exceptions to the Kaptein's rules were also found (Hore et al., 1983), but it is clear that the CIDNP method and the application of photo CIDNP to proteins and protein complexes has been very successful. It also initiated the biomolecular NMR research by Robert Kaptein.

The collaboration with Heinz Rüterjans on the photo CIDNP studies of the lac headpiece, the DNA binding domain of the lac repressor, in a complex with DNA, initiated the multidimensional and structural NMR studies by Robert Kaptein on the lac headpiece and its protein DNA complexes for which he is well known. The preconditions at that time for this research were very favourable; 2D NMR, as developed in Zurich by Richard Ernst, started to be applied to proteins, the method for obtaining the full assignment of protein NMR resonances by 2D NMR had just been developed by Kurt Wüthrich in Zurich, the synthesis of DNA oligonucleotides had just been developed by Jacques van Boom in Leiden, and the development of molecular dynamics simulation techniques of proteins were in full development in Groningen, with Herman Berendsen and Wilfred van Gunsteren. In a short time, Erik Zuiderweg of the group of Robert Kaptein achieved the full assignment of the NMR signals of the lac headpiece in a collaboration with Kurt Wüthrich (Zuiderweg et al., 1983a, b). This was followed by the determination of the 3D structure of the lac headpiece as an early NMR structure, using restrained molecular dynamics for the first time (Kaptein et al., 1985; Zuiderweg et al., 1985). Next, analogous to the sequential assignment procedure for proteins, a sequential NMR assignment method was developed for assigning the resonances in DNA using 2D NOE (nuclear Overhauser effect) spectra (Scheek et al., 1983, 1984; Boelens et al., 1985). Soon thereafter, a first model of a protein DNA complex by NMR was presented of the lac headpiece in a complex with the left half of the lac operator (Boelens et al., 1987). This model showed that the recognition helix of the lac headpiece would bind in the major groove of DNA, in line with biochemical data, but surprisingly, the orientation of the helix was $180^{\circ}$ opposite to what had been predicted on the basis of the X-ray structures of the dimeric Cro and lambda repressors (Ohlendorf et al., 1982; Pabo and Lewis, 1982). Essentially, this model was mainly based on two firm intermolecular NOEs, but the fact that this model was correct became evident from subsequent biochemical analysis of lac repressor DNA complexes by Benno Müller-Hill (Lehming et al., 1987, 1988) and was also demonstrated in detailed studies with highly optimised headpiece DNA complexes that showed a large number of intermolecular NOEs (Chuprina et al., 1993) and by subsequent studies of dimers of the lac headpiece bound to full $22 \mathrm{bp}$ lac operators (Lamerichs et al., 1989; Spronk et al., 1996, 1999; Kalodimos et al., 2002). These studies allowed a detailed understanding of the precise recognition of the operator by the lac repressor ( $20 \mathrm{bp}$ in a $4.6 \times 10^{6} \mathrm{bp}$ E. coli genome) through a multitude of intermolecular interactions. A further highlight was the study of the complex of a lac headpiece dimer with non-specific DNA 
(Kalodimos et al., 2004a, b). It turned out that the topologies of the specific and non-specific DNA complexes are very similar, with the recognition helices, in both cases, in the major groove of DNA. Crucial differences, however, were that the recognition helix in the non-specific complex was not as deeply positioned in the major groove, many side chains that formed hydrogen bonds in the major groove of the specific complex were redirected to the DNA phosphate backbone, and the hinge helices that stabilised the specific lac operator complexes were absent in the non-specific complex. The non-specific DNA binding also provided a model for 1D sliding of the lac repressor along the DNA, which explains the fast approach of the lac repressor towards the lac operator site (von Hippel and Berg, 1989; Kalodimos et al., 2004b). In fact, this sliding along the DNA phosphate backbone could even be directly studied by NMR (Loth et al., 2013).

In parallel to these biomolecular NMR studies, Kaptein's group also made visible contributions to NMR development. In addition to the photo CIDNP method as discussed above, the group developed, in collaboration with Wilfred van Gunsteren, restrained molecular dynamics for structure determination of biomolecules (van Gunsteren et al., 1984), methodology that can still be found in programmes such as Xplor and CNS (Brünger, 1992; Brünger et al., 1998). An iterative relaxation matrix approach (IRMA) using restrained molecular dynamics (MDs) was developed that allowed one to obtain precise distances from the 2D NOE spectra of biomolecules (Boelens et al., 1988, 1989a) for structure calculations, including DNA oligomers (Koning et al., 1991). Later, when combined with ensemble averaging, this approach allowed protein structure determination with accurate side chain geometries (Bonvin et al., 1994). Kaptein also made important contributions to the validation of structures determined by NMR. In collaboration with Kaptein, the group of Janet Thornton (UK) developed the widely used programme PROCHECK-NMR that enabled one to precisely analyse the violations of NMR restraints used in the structure calculations (Laskowski et al., 1996). A highly visible structural analysis by Kaptein's group was also the recalculation of more than 500 NMR structures in the Protein Data Bank (PDB), using restraints deposited in the Biological Magnetic Resonance Data Bank (BMRB), a study that was a cornerstone for NMR structure validation (Nederveen et al., 2005). For many years, Robert Kaptein chaired the NMR task force that advised the worldwide PDB and made the recommendations for nomenclature, representation of NMR structures and deposition of experimental NMR data in the databases for NMR of RCSB (PDB in the USA), European Bioinformatics Institute $(\mathrm{EBI})$ and $\mathrm{BMRB}$ (Markley et al., 1998), which further indicates the crucial role that Kaptein has played in this field. Other methodological developments by Kaptein's group were contributions to the development of 3D NMR. In a first paper of his group, 3D J-resolved NMR was demonstrated (Vuister and Boelens, 1987), which led to the development of 3D COSY-COSY and
COSY-NOESY by Christian Griesinger and Richard Ernst (Griesinger et al., 1987) and then to the first non-selective 3D NOESY-TOCSY and 3D NOESY-NOESY experiments in the group of Kaptein (Vuister et al., 1988; Boelens et al., 1989b). This paved the way for the highly successful heteronuclear 3D NMR developed later on in the USA (Marion et al., 1989; Zuiderweg and Fesik, 1989).

The visible research on the lac repressor research triggered a series of collaborative NMR studies of other DNA binding proteins with models for DNA binding. Examples are the Arc and Mnt repressors, which use a $\beta$ sheet for DNA recognition (Breg et al., 1990; Burgering et al., 1994), a collaboration with Robert Sauer of MIT in Boston; the DNA binding domain of the glucocorticoid hormone receptor with Keith Yamamoto (San Francisco) and Jan-Ake Gustaffson (Stockholm; Härd et al., 1990); the DNA binding domain of the retinoic acid hormone receptor with Paul van der Saag (Knegtel et al., 1993); the POU domain of the Oct-1 transcription factor with Peter van der Vliet in Utrecht (Dekker et al., 1993); the bacterial HU protein with Keith Wilson and Costas Vorgias of the European Molecular Biology Laboratory (EMBL; Vis et al., 1995); a model for the binding of ribosomal initiation factor IF1 to the 30 S ribosomal subunit with Claudio Gualerzi in Camerino, Italy (Sette et al., 1997); the human DNA repair complex ERCC1/XPF with Jan Hoeijmakers in Rotterdam (Tripsianes et al., 2005); and the Nand C-terminal domains of HIV integrase with Ronald Plasterk of the Netherlands Cancer Institute in Amsterdam (Eijkelenboom et al., 1995, 2000). Other structures determined were that of the complex of phospholipase A2 on a micellar surface and an inhibitor, with Bert Verweij in Utrecht (van den Berg et al., 1995a, b), and that of the complex of the lantibiotic nisin with lipid II, with Ben de Kruijff in Utrecht (Hsu et al., 2004).

The NMR studies of the photoactive yellow protein (PYP) and the blue light using FAD (BLUF) domain of AppA, a collaboration with the group of Klaas Hellingwerf in Amsterdam, combined the extensive expertise in Kaptein's group of laser light excitation in NMR with studies on protein structure and dynamics. After identifying the chromophore of PYP (Hoff et al., 1994), the group studied the photocycle intermediates of PYP. It could be shown that the light-excited state of PYP is highly dynamic and partially unfolds (Rubinstenn et al., 1998), a result that was in marked contrast to that obtained by X-ray crystallography. Whereas the structure of the ground state of wild-type PYP could be fully characterised by NMR (Düx et al., 1998; Craven et al., 2000), detailed analysis for the light-excited state turned out to be difficult since it was rapidly converted back to its ground state (Rubinstenn et al., 1998). Shortly after, however, it was found that the light-excited state of $\Delta 25$ PYP missing 25 $\mathrm{N}$-terminal residues was much longer lived (van der Horst et al., 2001). This enabled a full analysis of the structure, folding and dynamics of $\triangle 25 \mathrm{PYP}$ in the ground and lightexcited state (Bernard et al., 2005). It was found that, after 
light excitation of $\Delta 25 \mathrm{PYP}$, a large $\mathrm{N}$-terminal part of the protein largely unfolds, which settled NMR as a powerful tool for studying the photocycle intermediates of these photoreceptors.

After his official retirement in 2006, Robert Kaptein remained active in the field of bio NMR and spin hyperpolarisation. An important part of these activities was his Russian adventure. In 2011, Robert Kaptein was appointed as a leading scientist in the so-called Megagrant programme of the Russian Ministry of Science and Education, aimed at attracting leading researchers to Russia to initiate and lead cutting-edge research activities. The application had been prepared together with a team from Novosibirsk, led by Renad Sagdeev. The key participants from the Russian side, representing the Novosibirsk State University and International Tomography Center, were Alexandra Yurkovskaya, Nikita Lukzen, Igor Koptyug, Yuri Tsentalovich and Konstantin Ivanov. As usual, Kaptein's efforts have helped to improve research infrastructure (two modern NMR spectrometers could be purchased through the Megagrant). Thereafter, 2 years of research on spin hyperpolarisation and NMR followed, with frequent and extended stays of Kaptein in Novosibirsk (2012-2013). This highly stimulated progress in understanding the peculiarities of polarisation formation and polarisation transfer in experiments with parahydrogen. Notably, ideas of using level anti-crossings to describe polarisation transfer were developed during that period (Ivanov et al., 2013; Pravdivtsev et al., 2013a). These ideas were particularly rewarding in the case of SABRE (signal amplification by reversible exchange), which was, in those days, a new method for exploiting parahydrogen for NMR signal enhancement (Pravdivtsev et al., 2015). Robert Kaptein stimulated interest for this method in the Novosibirsk team, which later resulted in describing the magnetic field dependence of polarisation and also - as in the case of CIDNP - in formulating polarisation sign rules (Pravdivtsev et al., 2013b). The description of the role of level anti-crossings can be found in a review paper (Ivanov et al., 2014).

For his excellent research, Robert Kaptein was awarded the Gold Medal of the Royal Dutch Chemical Society and the Jean-Servais Stas Medal of the Société Chimique de Belgique in 1971 and the Holleman award of the Royal Netherlands Academy of Arts and Sciences in 1985. He was elected a member of the Royal Netherlands Academy of Arts and Sciences in 1989, a member of EMBO in 1991 and, in 1997, an honorary member of the National Magnetic Resonance Society of India. In 1980, he was appointed professor in Chemistry at the University of Groningen and in 1987 at the University of Utrecht. He has been research director of the Bijvoet Center for Biomolecular Research from 2000 to 2006, Secretary General of the Royal Dutch Academy of Sciences from 2002 to 2008, a member of various Scientific advisory boards such as EMBL, EBI, and ENS in Paris. He was a member and is a fellow of the International Society of Magnetic Resonance (ISMAR) council, chaired the Interna- tional Council on Magnetic Resonance in Biological Systems (ICMRBS) and was a member of the advisory board of the PDB.

As son of a teacher, Robert Kaptein had teaching in his genes. In addition to being an outstanding researcher, he was an excellent teacher. Still in Groningen, Kaptein was elected by students as one of their best teachers. These teaching skills came also into practice in teaching NMR to students at Utrecht. Together with Cees Hilbers in Nijmegen, Kaptein initiated advanced courses in biomolecular NMR, which trained many students and postdocs at that time in the Netherlands and which highly contributed to the development of NMR in the Netherlands. In total, Robert Kaptein trained 43 doctoral students, some already in Groningen but most of them in the NMR laboratory in Utrecht, and also hosted many postdocs and guest researchers. Many of them became professors thereafter. Together with Christian Griesinger and Hartmut Oschkinat, he initiated, in 1995, the EMBO course of multidimensional NMR in structural biology that was held for many years in Il Ciocco in Italy and trained many young scientists in NMR, who are currently active researchers in Europe and abroad. Robert Kaptein is an active member of the European NMR family. Next to being an outstanding scientist, he was an excellent organiser. Not only has he established a world-class biomolecular NMR lab in Utrecht but for several years he has been the director of the Bijvoet Center for Biomolecular Research and Secretary General of the Royal Netherlands Academy of Arts and Sciences (KNAW). From its start in 1991, Kaptein has been and still is associate editor of the Journal of Biomolecular NMR. He has also been editor or associate editor of other journals, including the Journal of Magnetic Resonance and Magnetic Resonance, Biopolymers, Structure and also the editor of series such as Focus on Structural Biology and Comprehensive Biomolecular Nuclear Magnetic Resonance.

An important, often underrated, aspect of NMR is organising and maintaining its infrastructure. Of course, many elements come into play, namely the skills and success of the researcher and willingness of the environment to breed, embed and support such infrastructure, and all at the same time. What turned out not to be possible in Groningen became a big success in Utrecht. When Kaptein was attracted to Utrecht in 1987, a $500 \mathrm{MHz}$ NMR was funded by the university, the $360 \mathrm{MHz}$ could be moved from Groningen, and a focussed research group could be built up. A few years later, the group could install a state-of-the-art $600 \mathrm{MHz} \mathrm{NMR}$. As one of the first, the group could install a $750 \mathrm{MHz}$ NMR in 1994 , and Utrecht became a national and European high-field NMR facility and expanded with an additional 500 and $600 \mathrm{MHz}$ instrument. In 2001, a state-of-the-art $900 \mathrm{MHz}$ NMR could be acquired, which was installed in a new building in 2003, the Nicolaas Bloembergen building, which houses all instruments of the Utrecht NMR group and which will also be the base for a $1.2 \mathrm{GHz}$ NMR, planned to be installed in Utrecht in 2021. Together with Ivano Bertini (later Claudio Luchinat 
and Lucia Banci) in Florence, Italy, and Heinz Rüterjans (and later Harald Schwalbe) in Frankfurt, Germany, these three NMR facilities have, since 1994, formed the core of a cluster of European NMR facilities open to researchers in Europe and worldwide. Robert Kaptein has played a pivotal role in initiating, organising and maintaining these infrastructures.

\section{References}

Akasaka, K., Fujii, S., and Kaptein, R.: Exposure of Aromatic Residues of Streptomyces Subtilisin Inhibitor. A Photo-CIDNP study, J. Biochem.-Tokyo, 89, 1945-1949, https://doi.org/10.1093/oxfordjournals.jbchem.a133396, 1981.

Bargon, J., Fischer, H., and Johnson, U.: KernresonanzEmissionslinien während rascher Radikalreaktionen. 1. Aufnahmeverfahren und Beispiele, Z. Naturforsch., 22a, 1551-1555, https://doi.org/10.1515/zna-1967-1014, 1967.

Berliner, L. J. and Kaptein, R.: NMR Characterization of Aromatic Residues of $\alpha$-Lactalbumins. Laser Photo Chemically Induced Dynamic Nuclear Polarization Nuclear Magnetic Resonance Studies of Surface Exposure, Biochemistry, 20, 799-807, https://doi.org/10.1021/bi00507a023, 1981.

Bernard, C., Houben, K., Derix, N. M., Marks, D., van der Horst, M. A., Hellingwerf, K. J., Boelens, R., Kaptein, R., and van Nuland, N. A. J.: The solution structure of a transient photoreceptor intermediate: $\Delta 25$ photoactive yellow protein, Structure, 13 , 953-962, https://doi.org/10.1016/j.str.2005.04.017, 2005.

Boelens, R., Scheek, R. M., Dijkstra, K., and Kaptein, R.: Sequential Assignment of Imino- and Amino-Proton Resonances in ${ }^{1} \mathrm{H}$ NMR Spectra of Oligonucleotides by Two-Dimensional NMR Spectroscopy. Application to a lac Operator Fragment, J. Magn. Reson., 62, 378-386, https://doi.org/10.1016/00222364(85)90207-0, 1985.

Boelens, R., Scheek, R. M., van Boom, J. H., and Kaptein, R.: Complex of lac repressor Headpiece with a 14 basepair lac operator fragment studied by two-dimensional nuclear magnetic resonance, J. Mol. Biol., 193, 213-216, https://doi.org/10.1016/0022-2836(87)90638-3, 1987.

Boelens, R., Koning, T. M. G., and Kaptein, R.: Determination of biomolecular structures from proton-proton NOE's using a relaxation matrix approach, J. Mol. Struct., 173, 299-311, https://doi.org/10.1016/0022-2860(88)80062-0, 1988.

Boelens, R., Koning, T. M. G., van der Marel, G. A., van Boom, J. H., and Kaptein, R.: Iterative procedure for structure determination from proton-proton NOE's using a full relaxation matrix approach. Application to a DNA octamer, J. Magn. Reson., 82, 290-308, https://doi.org/10.1016/0022-2364(89)900322, 1989a.

Boelens, R., Vuister, G. W., Koning, T. M. G., and Kaptein, R.: Observation of spin-diffusion in biomolecules by three-dimensional NOE-NOE spectroscopy, J. Am. Chem. Soc., 111, 8525-8526, https://doi.org/10.1021/ja00204a039, 1989b.

Bonvin, A. M. J. J., Vis, H., Breg, J. N., Burgering, M. J. M., Boelens, R., and Kaptein, R.: NMR solution structure of the Arc repressor using relaxation matrix calculations, J. Mol. Biol., 236, 328-341, https://doi.org/10.1006/jmbi.1994.1138, 1994.

Breg, J. N., van Opheusden, J. H. J., Burgering, M. J. M., Boelens, R., and Kaptein, R.: The structure of Arc repressor in solution. A family of $\beta$-sheet DNA-binding proteins, Nature, 346, 586-589, https://doi.org/10.1038/346586a0, 1990.

Brünger, A. T.: X-PLOR, Version 3.1, A System for X-ray Crystallography and NMR, Yale University Press, ISBN 9780300054026, 1992.

Brünger, A. T., Adams, P. D., Clore, G. M., DeLano, W. L., Gros, P., Grosse-Kunstleve, R. W., Jiang, J. S., Kuszewski, J., Nilges, M., Pannu, N. S., Read, R. J., Rice, L. M., Simonson, T., and Warren, G. L.: Crystallography \& NMR system: A new software suite for macromolecular structure determination, Acta Crystallogr. D, 54, 905-921, https://doi.org/10.1107/s0907444998003254, 1998.

Buck, F., Hahn, K. D., Zemann, W., Rüterjans, H., Sadler, J. R., Beyreuther, K., Kaptein, R., Scheek, R., and Hull, W. E.: NMR Study of the Interaction between the lac Repressor and the lac Operator, Eur. J. Biochem., 132, 321-327, https://doi.org/10.1111/j.1432-1033.1983.tb07365.x, 1983.

Burgering, M. J. M., Boelens, R., Gilbert, D. E., Breg, J. N., Knight, K. L., Sauer, R. T., and Kaptein, R.: Solution Structure of Dimeric Mnt Repressor (1-76), Biochemistry, 33, 15036-15045, https://doi.org/10.1021/bi00254a012, 1994.

Canioni, P., Cozzone, P. J., and Kaptein, R.: $360 \mathrm{MHz}$ Laser Photo-CIDNP of Porcine Pancreatic Colipase A. A Study of the Aromatic Surface Residues, FEBS Lett., 111, 219-222, https://doi.org/10.1016/0014-5793(80)80797-6, 1980.

Chuprina, V. P., Rullmann, J. A. C., Lamerichs, R. M. J. N., van Boom, J. H., Boelens, R., and Kaptein, R.: Structure of the Complex of lac Repressor Headpiece and an 11 Base Pair Half-Operator determined by NMR Spectroscopy and Restrained Molecular Dynamics, J. Mol. Biol., 234, 446-462, https://doi.org/10.1006/jmbi.1993.1598, 1993.

Closs, G. L. and Closs, L. E.: Induced dynamic nuclear spin polarization in reactions of photochemically and thermally generated triplet diphenylmethylene, J. Am. Chem. Soc., 91, 4549-4550, doi:https://doi.org/10.1021/ja01044a041, 1969.

Craven, C. J., Derix, N. M., Hendriks, J., Boelens, R., Hellingwerf, K. J., and Kaptein, R.: Probing the nature of the blueshifted intermediate of photoactive yellow protein in solation by NMR: Hydrogen-deuterium exchange data and $\mathrm{pH}$ studies, Biochemistry, 39, 14392-14399, https://doi.org/10.1021/bi001628p, 2000.

de Galan, L.: De instrumentele omwenteling: analytische chemie, in: De geschiedenis van de scheikunde in Nederland 3. De ontwikkeling van de chemie van 1945 tot het begin van de jaren tachtig, Delft University Press, Delft, 87-103, 2004.

Dekker, N., Cox, M., Boelens, R., Verrijzer, C. P., van der Vliet, P. C., and Kaptein, R.: Solution structure of the POUspecific DNA binding domain of Oct-1, Nature, 362, 852-855, https://doi.org/10.1038/362852a0, 1993.

de Marco, A., Mayo, K. H., Bartolotti, F., Scalia, S., Menegatti, E., and Kaptein, R.: Proton NMR and photo-CIDNP studies of peptide fragments obtained by controlled proteolysis of mouse epidermal growth factor, J. Biol. Chem., 261, 13510-13516, https://doi.org/10.1016/S0021-9258(18)67048-6, 1986a.

de Marco, A., Zetta, L., Petros, A. M., Llinas, M., Boelens, R., and Kaptein, R.: Kringle 4 from human plasminogen: A proton Magnetic Resonance study via two-dimensional photochemically induced dynamic nuclear polarization spectroscopy, Biochemistry, 25, 7918-7923, https://doi.org/10.1021/bi00372a020, 1986b. 
den Hollander, J. A. and Kaptein, R.: Radical Pair Substitution in CIDNP. Spin-Uncorrelated Geminate Radical Pairs, Chem. Phys. Lett., 41, 257-263, https://doi.org/10.1016/00092614(76)80805-6, 1976.

Drenth, W.: 120 jaar fysisch-organische chemie in Nederland 18741994, Utrecht, 2001.

Drenth, W. and Verhoeven, J. W.: Fysische-organische chemie: grote bloei na een aarzelend begin, in: De geschiedenis van de scheikunde in Nederland 3. De ontwikkeling van de chemie van 1945 tot het begin van de jaren tachtig, Delft University Press, Delft, 243-255, 2004.

Düx, P., Rubinstenn, G., Vuister, G. W., Boelens, R., Mulder, F. A. A., Hård, K., Hoff, W. D., Kroon, A. R., Crielaard, W., Hellingwerf, K. J., and Kaptein, R.: Solution structure and backbone dynamics of the photoactive yellow protein, Biochemistry, 37, 12689-12699, https://doi.org/10.1021/bi9806652, 1998.

Egmond, M. R., Hore, P. J., and Kaptein, R.: Photo-CIDNP ${ }^{1} \mathrm{H}-\mathrm{NMR}$ Studies of Bovine Pancreactic Phospholipase $\mathrm{A}_{2}$ and its Zymogen, Biochim. Biophys. Acta, 744, 23-27, https://doi.org/10.1016/0167-4838(83)90335-7, 1983.

Eijkelenboom, A. P. A. M., Lutzke, R. A. P., Boelens, R., Plasterk, R. H. A., Kaptein, R., and Hård, K.: The DNA-Binding domain of HIV-1 Iintegrase has an SH3-like fold, Nat. Struct. Biol., 2, 807-810, https://doi.org/10.1038/nsb0995-807, 1995.

Eijkelenboom, A. P. A. M., van den Ent, F. M. I., Wechselberger, R., Plasterk, R. H. A., Kaptein, R., and Boelens, R.: Refined solution structure of the dimeric N-terminal HHCC domain of HIV-2 integrase, J. Biomol. NMR, 18, 119-128, https://doi.org/10.1023/a:1008342312269, 2000.

Feeney, J., Roberts, G. C. K., Kaptein, R., Birdsall, B., Gronenborn, A., and Burgen, A. S. V.: Photo-CIDNP Studies of the Influence of Ligand Binding on the Surface Accessibility of Aromatic Residues in Dihydrofolate Reductase, Biochemistry, 19, 2466-2472, https://doi.org/10.1021/bi00552a026, 1980.

Freeman, R., Hill, H. D. W., and Kaptein, R.: ProtonDecoupled NMR Spectra of Carbon-13 With the Nuclear Overhauser Effect Suppressed, J. Magn. Reson., 7, 327-329, https://doi.org/10.1016/0022-2364(72)90194-1, 1972.

Garner, W. H., Spector, A., Schleich, T., and Kaptein, R.: Determination of the solvent accessibility of specific aromatic residues in gamma-crystallin by PhotoCIDNP NMR measurements, Curr. Eye Res., 3, 127-135, https://doi.org/10.3109/02713688408997194, 1984.

Garssen, G. J., Kaptein, R., Schoenmakers, J. G. G., and Hilbers, C. W.: A photo-CIDNP study of the interaction of oligonucleotides with gene-5 protein of bacteriophage M13, P. Natl. Acad. Sci. USA, 75, 5281-5285, https://doi.org/10.1073/pnas.75.11.5281, 1978.

Griesinger, C., Sørensen, O. W., and Ernst, R. R.: A practical approach to three-dimensional NMR spectroscopy, J. Magn. Reson., 73, 574-579, https://doi.org/10.1016/0022-2364(87)900278, 1987.

Härd, T., Kellenbach, E., Boelens, R., Maler, B. A., Dahlman, K., Freedman, L. P., Carlstedt-Duke, J., Yamamoto, K. R., Gustafsson, J. A., and Kaptein, R.: Solution Structure of the Glucocorticoid Receptor DNA-Binding Domain, Science, 249, 157-160, https://doi.org/10.1126/science.2115209, 1990.

Hoff, W. D., Düx, P., Hård, K., de Vreese, B., Nugteren-Roodzant, I. M., Crielaard, W., Boelens, R., Kaptein, R., van Beeumen, J., and
Hellingwerf, K. J.: Thiol ester-linked p-coumaric acid as a new photoactive cofactor in a rhodopsin-like protein, Biochemistry, 33, 13959-13962, https://doi.org/10.1021/bi00251a001, 1994.

Hore, P. J. and Kaptein, R.: Photo-CIDNP of Biological Molecules using Continuous Wave and Time-Resolved Methods, ACS Symp. Ser., 191, 285-318, https://doi.org/10.1021/bk-19820191.ch015, 1982.

Hore, P. J., Zuiderweg, E. R. P., Kaptein, R., and Dijkstra, K.: Flash Photolysis NMR. CIDNP Time Dependence in Cyclic Photochemical Reactions, Chem. Phys. Lett., 83, 376-383, https://doi.org/10.1016/0009-2614(81)85483-8, 1981.

Hore, P. J., Volbeda, A., Dijkstra, K., and Kaptein, R.: Photo-Reduction of Flavin by NADH - a flash-photolysis photo-CIDNP study, J. Am. Chem. Soc., 104, 6262-6267, https://doi.org/10.1021/ja00387a017, 1982.

Hore, P. J., Stob, S., Kemmink, J., and Kaptein, R.: An Exception to the CIDNP Sign Rules, Chem. Phys. Lett., 98, 409-413, https://doi.org/10.1016/0009-2614(83)80077-3, 1983.

Hsu, S. T. D., Breukink, E., Tischenko, E., Lutters, M. A. G., de Kruijff, B., Kaptein, R., Bonvin, A. M. J. J., and van Nuland, N. A. J.: The nisin-lipid II complex reveals a pyrophosphate cage that provides a blueprint for novel antibiotics, Nat. Struct. Mol. Biol., 11, 963-967, https://doi.org/10.1038/nsmb830, 2004.

Ivanov, K. L., Stass, D. V., Kalneus, E. V., Kaptein, R., and Lukzen, N. N.: Theoretical Treatment of Degenerate Electron Exchange and Dimerization in Spin Dynamics of Radical Ion Pairs as Observed by Magnetic Field Effects, Appl. Magn. Reson., 44, 217 232, https://doi.org/10.1007/s00723-012-0413-y, 2013.

Ivanov, K. L., Pravdivtsev, A. N., Yurkovskaya, A. V., Vieth, H. M., and Kaptein, R.: The role of level anti-crossings in nuclear spin hyperpolarization, Prog. Nucl Mag. Res. Sp., 81, 1-36, https://doi.org/10.1016/j.pnmrs.2014.06.001, 2014.

Jansen, E. H. J. M., Meyer, H., de Haas, G. H., and Kaptein, R.: A Photo-CIDNP Study of Pancreatic Phospholipase $A_{2}$. NMR Assignments of some Aromatic Residues, J. Biol. Chem., 253, 6346-6347, https://doi.org/10.1016/S0021-9258(19)46939$1,1978$.

Jansen, E. H. J. M., van Scharrenburg, G. J. M., Slotboom, A. J., de Haas, G. H., and Kaptein, R.: A $360 \mathrm{MHz}$ Photo-CIDNP Study of Bovine Pancreatic Phospholipase $\mathrm{A}_{2}$. Observation of a $\mathrm{pH}$ Dependent Conformational Change, J. Am. Chem. Soc., 101, 7397 7399, https://doi.org/10.1021/ja00518a045, 1979.

Kalodimos, C. G., Bonvin, A. M. J. J., Salinas, R. K. Wechselberger, R., Boelens, R., and Kaptein, R.: Plasticity in protein-DNA recognition: lac repressor interacts with its natural operator $O 1$ through alternative conformations of its DNA-binding domain, EMBO J., 21, 2866-2876, https://doi.org/10.1093/emboj/cdf318, 2002.

Kalodimos, C. G., Biris, N., Bonvin, A. M. J. J., Levandoski, M. M., Guennuegues, M., Boelens, R., and Kaptein, R.: Structure and flexibility adaptation in nonspecific and specific protein-DNA complexes, Science, 305, 386-389, https://doi.org/10.1126/science.1097064, 2004a.

Kalodimos, C. G., Boelens, R., and Kaptein, R.: Toward an integrated model of protein-DNA recognition as inferred from NMR studies on the Lac repressor system, Chem. Rev., 104, 35673586, https://doi.org/10.1021/cr0304065, 2004b. 
Kaptein, R.: Simple Rules for Chemically Induced Dynamic Nuclear Polarization, J. Chem. Soc. Chem. Comm., 732-733, https://doi.org/10.1039/c29710000732, 1971a.

Kaptein, R.: Chemically Induced Dynamic Nuclear Polarization, PhD thesis, Leiden University, the Netherlands, 1971b.

Kaptein, R.: Chemically Induced Dynamic Nuclear Polarization. IX. Reactions competitive with germinate recombination of radical pairs, J. Am. Chem. Soc., 94, 6262-6269, https://doi.org/10.1021/ja00773a002, 1972a.

Kaptein, R.: Chemically Induced Dynamic Nuclear Polarization. VIII. Spin Dynamics and Diffusion of Radical Pairs, J. Am. Chem. Soc., 94, 6251-6262, https://doi.org/10.1021/ja00773a001, 1972b.

Kaptein, R.: Photo-CIDNP Studies of Proteins, in: Biological Magnetic Resonance, 1st edn., edited by: Berliner, L. J. and Rueben, J., Springe US, Biological Magnetic Resonance, 4, 145-191, 1982.

Kaptein, R.: The Early Days of CIDNP, in: Encyclopedia of Magnetic Resonance, edited by: Harris, R. K. and Wasylishen, R., John Wiley, Chichester, https://doi.org/10.1002/9780470034590.emrhp0092, 2007.

Kaptein, R. and den Hollander, J. A.: Chemically Induced Dynamic Nuclear Polarization. X. On the Magnetic Field Dependence, J. Am. Chem. Soc., 94, 6269-6280, https://doi.org/10.1021/ja00773a003, 1972.

Kaptein, R. and Oosterhoff, L. J.: Chemically induced dynamic nuclear polarization. III. (anomalous multiplets of radical coupling and disproportionation products), Chem. Phys. Lett., 4, 214-216, https://doi.org/10.1016/0009-2614(69)80105-3, 1969a.

Kaptein, R. and Oosterhoff, L. J.: Chemically induced dynamic nuclear polarization. II. (Relation with anomalous ESR spectra), Chem. Phys. Lett., 4, 195-197, https://doi.org/10.1016/00092614(69)80098-9, 1969b.

Kaptein, R., Fráter-Schröder, M., and Oosterhoff, L. J.: Chemically Induced Dynamic Nuclear Polarization. V. NMR Enhancements in Biradical Products, Chem. Phys. Lett., 12, 16-19, https://doi.org/10.1016/0009-2614(71)80606-1, 1971a.

Kaptein, R., Verheus, F. W., and Oosterhoff, L. J.: Chemically Induced Dynamic Nuclear Polarization. VI. Sign Reversal of the Polarization in the Reaction of Isobutyryl Peroxide with Bromotrichloromethane, J. Chem. Soc. Chem. Comm., 877-878, https://doi.org/10.1039/c29710000877, 1971b.

Kaptein, R., Brokken-Zijp, J., and de Kanter, F. J. J.: Chemically Induced Dynamic Nuclear Polarization. XI. Thermal Decomposition of Acetyl Peroxide, J. Am. Chem. Soc., 94, 6280-6287, https://doi.org/10.1021/ja00773a004, 1972.

Kaptein, R., Freeman, R., Hill, H. D. W., and Bargon, J.: Carbon13 CIDNP in the Reversible Addition of Pentafluorobenzoyloxy Radicals to Chlorobenzene, J. Chem. Soc. Chem. Comm., 953954, https://doi.org/10.1039/c39730000953, 1973.

Kaptein, R., Freeman, R., and Hill, H. D. W.: Carbon-13 CIDNP from Biradicals in the Photolysis of Cyclic Ketones, Chem. Phys. Lett., 26, 104-107, https://doi.org/10.1016/00092614(74)89096-2, 1974.

Kaptein, R., van Leeuwen, P. W. N. M., and Huis, R.: CIDNP Study of Homolytic Substitution $\left(S_{\mathrm{H}} 2\right)$ Reactions at Metal Centres, J. Chem. Soc. Chem. Comm., 568-569, https://doi.org/10.1039/c39750000568, 1975.
Kaptein, R., Dijkstra, K., and Nicolay, K.: Laser Photo-CIDNP as a Surface Probe for Proteins in Solution, Nature, 274, 293-294, https://doi.org/10.1038/274293a0, 1978.

Kaptein, R., Nicolay, K., and Dijkstra, K.: Photo-CIDNP in Nucleic Acid Bases and Nucleotides, J. Chem. Soc. Chem. Comm., 1092-1094, https://doi.org/10.1039/c39790001092, 1979.

Kaptein, R., Zuiderweg, E. R. P., Scheek, R. M., Boelens, R., and van Gunsteren, W. F.: A Protein Structure from Nuclear Magnetic Resonance Data: lac Repressor Headpiece, J. Mol. Biol., 182, 179-182, https://doi.org/10.1016/0022-2836(85)90036-1, 1985.

Knegtel, R. M. A., Katahira, M., Schilthuis, J. G., Bonvin, A. M. J. J., Boelens, R., Eib, D., van der Saag, P. T., and Kaptein, R.: The solution structure of the human retinoic acid receptor-beta DNA-binding domain, J. Biomol. NMR, 3, 1-17, https://doi.org/10.1007/bf00242472, 1993.

Koning, T. M. G., Boelens, R., van der Marel, G. A., van Boom, J. H., and Kaptein, R.: Structure determination of a DNA octamer in solution by NMR spectroscopy. The effect of fast local motions, Biochemistry, 30, 3787-3797, https://doi.org/10.1021/bi00229a028, 1991.

Lamerichs, R. M. J. N., Boelens, R., van der Marel, G. A., van Boom, J. H., Kaptein, R., Buck, F., Fera, B., and Rüterjans, H.: Proton NMR study of a complex between the lac repressor headpiece and a 22 base pair symmetric lac operator, Biochemistry, 28, 2985-2991, https://doi.org/10.1021/bi00433a037, 1989.

Laskowski, R. A., Rullmann, J. A. C., MacArthur, M. W., Kaptein, R., and Thornton, J. M.: AQUA and PROCHECKNMR: Programs for checking the quality of protein structures solved by NMR, J. Biomol. NMR, 8, 477-486, https://doi.org/10.1007/bf00228148, 1996.

Lehming, N., Sartorius, J., Niemöller, M., Genenger, G., von Wilcken-Bergmann, B., and Müller-Hill, B.: The interaction of the recognition helix of lac repressor with lac operator, EMBO J., 6, 3145-3153, https://doi.org/10.1002/j.14602075.1987.tb02625.x, 1987.

Lehming, N., Sartorius, J., Oehler, S., von Wilcken-Bergmann, B., and Müller-Hill, B.: Recognition helices of lac and lambda repressor are oriented in opposite directions and recognize similar DNA sequences, P. Natl. Acad. Sci. USA, 85, 7947-7951, https://doi.org/10.1073/pnas.85.21.7947, 1988.

Lenstra, J. A., Bolscher, B. G. J. M., Stob, S., Beintema, J. J., and Kaptein, R.: The Aromatic Residues of Bovine Ribonuclease Studied by ${ }^{1} \mathrm{H}$ Nuclear Magnetic Resonance, Eur. J. Biochem., 98, 385-397, https://doi.org/10.1111/j.14321033.1979.tb13198.x, 1979.

Loth, K., Gnida, M., Romanuka, J., Kaptein, R., and Boelens, R.: Sliding and target location of DNA-binding proteins:an NMR view of the lac repressor system, J. Biomol. NMR, 56, 41-49, https://doi.org/10.1007/s10858-013-9723-0, 2013.

Marion, D., Driscoll, P. C., Kay, L. E., Wingfield, P. T., Bax, A., Gronenborn, A. M., and Clore, G. M.: Overcoming the overlap problem in the assignment of proton NMR spectra of larger proteins by use of three-dimensional heteronuclear protonnitrogen-15 Hartmann-Hahn-multiple quantum coherence and nuclear Overhauser-multiple quantum coherence spectroscopy: application to interleukin 1.beta, Biochemistry, 28, 6150-6156, https://doi.org/10.1021/bi00441a004, 1989.

Markley, J. L., Bax, A., Arata, Y., Hilbers, C. W., Kaptein, R., Sykes, B. D., Wright, P. E., and Wüthrich, K.: Recommendations 
for the presentation of NMR structures of proteins and nucleic acids - (IUPAC Recommendations 1998), Pure Appl. Chem., 70, 117-142, https://doi.org/10.1351/pac199870010117, 1998.

Moonen, C. T. W., Hore, P. J., Müller, F., Kaptein, R., and Mayhew, S. G.: A Photo-CIDNP Study of the active sites of Megashaera elsdenii and Clostridium MP flavodoxins, FEBS Lett., 149, 141146, https://doi.org/10.1016/0014-5793(82)81090-9, 1982.

Morozova, O. B., Kiryutin, A. S., Sagdeev, R. Z., and Yurkovskaya, A. V.: Electron transfer between guanosine radical and amino acids in aqueous solution. 1. Reduction of guanosine radical by tyrosine, J. Phys. Chem. B, 111, 7439-7448, https://doi.org/10.1021/jp067722i, 2007.

Morozova, O. B., Kiryutin, A. S., and Yurkovskaya, A. V.: Electron transfer between guanosine radicals and amino acids in aqueous solution. II. Reduction of guanosine radicals by tryptophan, J. Phys. Chem. B, 112, 2747-2754, https://doi.org/10.1021/jp0752318, 2008.

Morozova, O. B., Kaptein, R., and Yurkovskaya, A. V.: Reduction of guanosyl radical by cysteine and cysteine-glycine studied by time-resolved CIDNP, J. Phys. Chem. B, 116, 8058-8063, https://doi.org/10.1021/jp301760b, 2012.

Morozova, O. B., Kaptein, R., Sagdeev, R. Z., and Yurkovskaya, A. V.: Reduction of Guanosyl Radicals in Reactions with Proteins Studied by TR-CIDNP, Appl. Magn. Reson., 44, 233-245, https://doi.org/10.1007/s00723-012-0403-0, 2013.

Nederveen, A. J., Doreleijers, J. F., Vranken, W., Miller, Z., Spronk, C. A. E. M., Nabuurs, S. B., Güntert, P., Livny, M., Markley, J. L., Nilges, M., Ulrich, E. L., Kaptein, R., and Bonvin, A. M. J. J.: RECOORD: A recalculated coordinate database of 500+ proteins from the PDB using restraints from the BioMagResBank, Proteins, 59, 662-672, https://doi.org/10.1002/prot.20408, 2005.

Norton, R. S., Beress, L., Stob, S., Boelens, R., and Kaptein, R.: Photochemically induced dynamic nuclear polarisation NMR study of the aromatic residues of sea-anemone polypeptide cardiac stimulants, Eur. J. Biochem., 157, 343-346, https://doi.org/10.1111/j.1432-1033.1986.tb09674.x, 1986.

Ohlendorf, D. H., Anderson, W. F., Fisher, R. G., Takeda, Y., and Matthews, B. W.: The molecular basis of DNA-protein recognition inferred from the structure of cro repressor, Nature, 298, 718-723, https://doi.org/10.1038/298718a0, 1982.

Pabo, C. O. and Lewis, M.: The operator-binding domain of lambda repressor: structure and DNA recognition, Nature, 298, 443-447, https://doi.org/10.1038/298443a0, 1982.

Pravdivtsev, A. N., Ivanov, K. L., Kaptein, R., and Yurkovskaya, A. V.: Theoretical Study of Dipolar Relaxation of Coupled Nuclear Spins at Variable Magnetic Field, Appl. Magn. Reson., 44, 23 39, https://doi.org/10.1007/s00723-012-0404-z, 2013 a.

Pravdivtsev, A. N., Yurkovskaya, A. V., Kaptein, R., Miesel, K., Vieth, H. M., and Ivanov, K. L.: Exploiting level anti-crossings for efficient and selective transfer of hyperpolarization in coupled nuclear spin systems, Phys. Chem. Chem. Phys., 15, 1466014669, https://doi.org/10.1039/c3cp52026a, 2013b.

Pravdivtsev, A. N., Ivanov, K. L., Yurkovskaya, A. V., Petrov, P. A., Limbach, H. H., Kaptein, R., and Vieth, H. M.: Spin polarization transfer mechanisms of SABRE: A magnetic field dependent study, J. Magn. Reson., 261, 73-82, https://doi.org/10.1016/j.jmr.2015.10.006, 2015.

Redfield, C., Dobson, C. M., Scheek, R. M., Stob, S., and Kaptein, R.: Surface accessibility of aromatic residues in hu- man lysozyme using photochemically induced dynamic nuclear polarization NMR spectroscopy, FEBS Lett., 185, 248-252, https://doi.org/10.1016/0014-5793(85)80916-9, 1985.

Rubinstenn, G., Vuister, G. W., Mulder, F. A. A., Dux, P. E., Boelens, R., Hellingwerf, K. J., and Kaptein, R.: Structural and dynamic changes of photoactive yellow protein during its photocycle in solution, Nat. Struct. Biol., 5, 568-570, https://doi.org/10.1038/823, 1998.

Scheek, R. M., Kaptein, R., and Verhoeven, J. W.: Resolution of specific histidine resonances in the $360 \mathrm{MHz}{ }^{1} \mathrm{H}$ NMR spectrum of glyceraldehyde-3-phosphate dehydrogenase, a 145000 molecular weight protein, by photo-CIDNP, FEBS Lett., 107, 288-290, https://doi.org/10.1016/0014-5793(79)80392-0, 1979.

Scheek, R. M., Russo, N., Boelens, R., and Kaptein, R.: Sequential resonance assignments in DNA proton NMR spectra by twodimensional NOE spectroscopy, J. Am. Chem. Soc., 105, 2914 2916, https://doi.org/10.1021/ja00347a075, 1983.

Scheek, R. M., Boelens, R., Russo, N., van Boom, J. H., and Kaptein, R.: Sequential resonance assignments in proton NMR spectra of oligonucleotides by twodimensional NMR spectroscopy, Biochemistry, 23, 1371-1376, https://doi.org/10.1021/bi00302a006, 1984.

Sette, M., van Tilborg, P. J. A., Spurio, R., Kaptein, R., Paci, M., Gualerzi, C. O., and Boelens, R.: The structure of the translational initiation factor IF1 from E. coli contains an oligomer-binding motif, EMBO J., 16, 1436-1443, https://doi.org/10.1093/emboj/16.6.1436, 1997.

Siebert, H. C., Andre, S., Reuter, G., Gabius, H. J., Kaptein, R., and Vliegenthart, J. F. G.: Effect of enzymatic desialylation of human serum amyloid $\mathrm{P}$ component on surface exposure of laser photo CIDNP (chemically induced dynamic nuclear polarization) - reactive histidine, tryptophan and tyrosine residues, FEBS Lett., 371, 13-16, https://doi.org/10.1016/0014-5793(95)00845z, 1995.

Siebert, H. C., Kaptein, R., Beintema, J. J., Soedjanaatmadja, U. M., Wright, C. S., Rice, A., Kleineidam, R. G., Kruse, S., Schauer, R., Pouwels, P. J. W., Kamerling, J. P., Gabius, H. J., and Vliegenthart, J. F. G.: Carbohydrate-protein interaction studies by laser photo CIDNP NMR methods, Glycoconjugate J., 14, 531-534, https://doi.org/10.1023/a:1018572023153, 1997.

Spronk, C. A. E. M., Slijper, M., van Boom, J. H., Kaptein, R., and Boelens, R.: Formation of the hinge helix in the lac repressor is induced upon binding to the lac operator, Nat. Struct. Biol., 3, 916-919, https://doi.org/10.1038/nsb1196-916, 1996.

Spronk, C. A. E. M., Folkers, G. E., Noordman, A. M. G. W., Wechselberger, R., van den Brink, N., Boelens, R., and Kaptein, R.: Hinge-helix formation and DNA bending in various lac repressor-operator complexes, The EMBO J., 18, 6472-6480, https://doi.org/10.1093/emboj/18.22.6472, 1999.

Tripsianes, K., Folkers, G., AB, E., Das, D., Odijk, H., Jaspers, N. G. J., Hoeijmakers, J. H. J., Kaptein, R., and Boelens, R.: The structure of the human ERCC1/XPF interaction domains reveals a complementary role for the two proteins in nucleotide excision repair, Structure, 13, 1849-1858, https://doi.org/10.1016/j.str.2005.08.014, 2005.

van den Berg, B., Tessari, M., Boelens, R., Dijkman, R., de Haas, G. H., Kaptein, R., and Verheij, H. M.: NMR structures of phospholipase $\mathrm{A}_{2}$ reveal conformational changes 
during interfacial activation, Nat. Struct. Biol., 2, 402-406, https://doi.org/10.1038/nsb0595-402, 1995a.

van den Berg, B., Tessari, M., Boelens, R., Dijkman, R., Kaptein, R., de Haas, G. H., and Verheij, H. M.: Solution structure of porcine pancreatic phospholipase $\mathrm{A}_{2}$ complexed with micelles and a competitive inhibitor, J. Biomol. NMR, 5, 110-121, https://doi.org/10.1007/bf00208802, 1995b.

van der Horst, M. A., van Stokkum, I. H., Crielaard, W., and Hellingwerf, K. J.: The role of the N-terminal domain of photoactive yellow protein in the transient partial unfolding during signalling state formation, FEBS Lett., 497, 26-30, https://doi.org/10.1016/s0014-5793(01)02427-9, 2001.

van der Waals, J. and Hilbers, K.: Moleculen doorgrond: kwantumchemie en spectroscopie, in: De geschiedenis van de scheikunde in Nederland 3, De ontwikkeling van de chemie van 1945 tot het begin van de jaren tachtig, Delft University Press, Delft, 105129, 2004.

van Gunsteren, W. F., Kaptein, R., and Zuiderweg, E. R. P.: Use of molecular dynamics computer simulations when determining protein structure by $2 \mathrm{D}-\mathrm{NMR}$, in: Proceedings of the NATO/CECAM Workshop on Nucleic Acid Conformation and Dynamics, edited by: Olsen, W. K., Centre de Calcul Atomique et Moleculaire, Orsay, 79-82, 1984.

van Leeuwen, P. W. N. M., Kaptein, R., Huis, R., and Kalisvaart, W. I.: CIDNP Studies of Reactions of Alkyllead compounds with Hexachloroacetone and Hexachlorocyclopentadiene, J. Organomet. Chem., 93, C5-C7, https://doi.org/10.1016/s0022328x(00)94154-8, 1975.

Vis, H., Mariani, M., Vorgias, C. E., Wilson, K. S., Kaptein, R., and Boelens, R.: Solution structure of the HU protein from Bacillus stearothermophilus, J. Mol. Biol., 254, 692-703, https://doi.org/10.1006/jmbi.1995.0648, 1995.

von Hippel, P. H. and Berg, O. G.: Facilitated target location in biological systems, J. Biol. Chem., 264, 675-678, https://doi.org/10.1016/S0021-9258(19)84994-3, 1989.

Vuister, G. W. and Boelens, R.: Three-dimensional Jresolved NMR spectroscopy, J. Magn. Reson., 73, 328-333, https://doi.org/10.1016/0022-2364(87)90205-8, 1987.
Vuister, G. W., Boelens, R., and Kaptein, R.: Non-selective three-dimensional NMR spectroscopy. The 3D NOEHOHAHA experiment, J. Magn. Reson., 80, 176-185, https://doi.org/10.1016/0022-2364(88)90072-8, 1988.

Ward, H. R. and Lawler, R. G.: Nuclear magnetic resonance emission and enhanced absorption in rapid organometallic reactions, J. Am. Chem. Soc., 89, 5518-5519, https://doi.org/10.1021/ja00997a078, 1967.

Zetta, L., Kaptein, R., and Hore, P. J.: A Photo-CIDNP investigation of tyrosine mobility and exposure in human beta-endorphin in the presence of phospholipid micelles, FEBS Lett., 145, 277-280, https://doi.org/10.1016/0014-5793(82)80182-8, 1982.

Zetta, L., Böhmer, V., and Kaptein, R.: Rapid hydrogen atom transfer in oligophenols. A photo-CIDNP study, J. Magn. Reson., 76, 587-591, https://doi.org/10.1016/0022-2364(88)90363-0, 1988.

Zuiderweg, E. R. P. and Fesik, S. W.: Heteronuclear three-dimensional NMR spectroscopy of the inflammatory protein C5a, Biochemistry, 28, 2387-2391, https://doi.org/10.1021/bi00432a008, 1989.

Zuiderweg, E. R. P., Kaptein, R., and Wüthrich, K.: Secondary structure of the lac repressor DNA-binding domain by two-dimensional $1 \mathrm{H}$ nuclear magnetic resonance in solution, P. Natl. Acad. Sci.-Biol., 80, 5837-5841, https://doi.org/10.1073/pnas.80.19.5837, 1983a.

Zuiderweg, E. R. P., Kaptein, R., and Wüthrich, K.: Sequencespecific resonance assignments in the ${ }^{1} \mathrm{H}$ nuclear-magneticresonance spectrum of the Lac repressor DNA-binding domain 1-51 from Escherichia coli by two-dimensional spectroscopy, Eur. J. Biochem., 137, 279-292, https://doi.org/10.1111/j.14321033.1983.tb07827.x, 1983b.

Zuiderweg, E. R. P., Scheek, R. M., Boelens, R., van Gunsteren, W. F., and Kaptein, R.: Determination of protein structures from nuclear magnetic resonance data using a restrained molecular dynamics approach: The lac repressor DNA binding domain, Biochimie, 67, 707-715, https://doi.org/10.1016/s03009084(85)80158-9, 1985. 